\title{
The Body Politic Metaphor in Communal and Post-Communal Italy - Some Remarks on the Case of Lombardy
}

\author{
Andrea Gamberini \\ University of Milan \\ andrea.gamberini@unimi.it
}

\begin{abstract}
This paper uses the body politic metaphor to explore the dialectic of power between different political players in communal and post-communal Lombardy. On the one hand, notions of corporeal links, drawing upon an ancient and venerable tradition, were key strands of public debate on state formation in the Late Middle Ages. On the other hand, there were distinctively communal and postcommunal discourses based upon the body politic metaphor. My purpose is to investigate all of these aspects through analysis of the so-called "pragmatic writings" (such as letters, decrees, notarial deeds), sources usually overlooked by historians of political thought. As is shown in this paper, the novelty of this approach makes it possible to appreciate corporeal metaphors as performative tools and instruments of political action.
\end{abstract}

\section{Keywords}

City communes - Lombardy - Duchy of Milan - Body politic - political discourse

\section{Introduction}

The purpose of this paper is to trace a brief history of the use of corporeal metaphors in political discourse in the Po Valley (i.e., Lombardy) in the communal and post-communal ages. As will be shown, there are many sources in political literature that establish an analogy between the political body and the human body. This is not particularly surprising; medieval Europe inherited corporeal metaphors from diverse cultural traditions, ranging from the theological tradition (think of the famous image of the body and limbs handed down from the first of Paul's Letters to the Corinthians 
- "But now are they many members, but yet one body"; 12:20) to the classical tradition (going from Plato and Aristotle to Livy). ${ }^{1}$

These terminological genealogies have been extensively investigated by historians of political thought. The principal focus here will be on the use of these metaphors in everyday political practice. For historians of medieval society and the institutions of the Middle Ages, the interest lies, above all, in the concrete use to which various actors put the body politic metaphor. The different contexts in which they were used not only conferred different meanings to the metaphors used at any given time, but - as we will try to show - also present us with slight but significant variations of the same metaphor. Finally, we will also see that the use of the body politic metaphor sometimes conveyed much deeper meanings than might be discerned through a superficial reading.

The goal of this essay is to bring out all these aspects as they would have applied in everyday discourses and exchanges. To this end, I have deliberately omitted the analytical foundations of the great authors, of the famous works of medieval political thought and of the treatises; choosing instead to dwell upon the so-called "pragmatic writings" (as Hagen Keller has termed them), such as letters, decrees, notarial deeds and chronicles. ${ }^{2}$ Through those sources, it is possible to explore and reconstruct the daily dialogue of the political players of communal Italy and that of the regional states. It is only through such sources that the historian can investigate corporeal metaphors as instruments of action.

${ }^{1}$ For a broad chronology, see Judith Schlanger, Les métaphores de l'organisme (Paris, 1971); for the Middle Ages, see also Jacques Le Goff, "Head or Heart? The Political Use of Body Metaphors in the Middle Ages" (trans. from the French by Patricia Ranum), in Michel Feher, ed., Fragments for a History of the Human Body (New York, 1989), vol. 3, 13-27; Jacques Le Goff and Nicolas Truong, Une histoire du corps au Moyen Age (Paris, 2003); Cary J. Nederman, "Body Politics. The Diversification of Organic Metaphors in Later Middle Ages," Il pensiero politico medievale, 2 (2004), 59-87; Gianluca Briguglia, Il corpo vivente dello Stato. Una metafora politica (Milan, 2006); Vasileios Syros, "Galenic Medicine and Social Stability in Early Modern Florence and the Islamic Empires,” Journal of Early Modern History, 17 (2013), 161-213.

${ }^{2}$ Hagen Keller and Jörg W. Busch, eds., Statutencodices des 13. Jahrhunderts als Zeugen pragmatischer Schriftlichkeit. Die Handschriften von Como, Lodi, Novara, Pavia und Voghera (Munich, 1991); Christel Meier, Volker Honemann, Hagen Keller and Rudolf Suntrup, eds., Pragmatische Dimensionen mittelalterlicher Schriftkultur (Munich, 2002). Cf. also Andrea Gamberini, “The Language of Politics and the Process of State-Building: Approaches and Interpretations," in Andrea Gamberini and Isabella Lazzarini, eds., The Italian Renaissance State (Cambridge, 2012), 406-424. 


\section{The Use of Corporeal Metaphors between the Twelfth and Fifteenth Centuries}

Having clarified the objective and methodological approach for this study, we look to the political context within which the corporeal metaphors investigated here found their broad application. The area where the analogy between the political body and the human body appears for the first time - at least in the pragmatic sources here being examined - is that of the relationship between city and countryside. It is here that we begin, with this urban-rural dichotomy, analogous to two members of the one body.

At least until the tenth century, almost everywhere in northern Italy, the countryside had followed the political destiny of the cities to such an extent that the civitates and the surrounding territories were regarded as continuous entities. The city since Roman times was the seat of civil power, and the countryside therefore gravitated towards it from an administrative and jurisdictional perspective. These arrangements, which we may define as urban-centric, remained unchanged even as one power succeeded the next over the centuries: from the Goths to the Byzantines, and from the Lombards to the Franks. The territorialization of the powers of the bishops facilitated this outcome. Bishops established their headquarters in the cities, which, in turn, became centers of ecclesiastical districts that extended to the rural world. In the transitional period between late antiquity and the Early Middle Ages, both the civil and ecclesiastical ordering of territories contributed toward keeping cities and countryside together, thereby creating an institutional framework for commercial relationships that had long seen the urban market absorbing the surplus products of the rural world. ${ }^{3}$

However, this century-old union underwent a rupture in the post-Carolingian era. The disintegration of the empire resulted in the political fragmentation of the large public districts, the counties (in Latin: comitatus). No longer held together by the jurisdiction of a count, cities and countryside took different paths. In rural areas, the collapse of centralized power favored the emergence of manors and lordships, while in the city, the disappearance of the counts led to the strengthening of the civil role of the bishops, who became the true holders of power in the urban environment and was sometimes expressly recognized as such even by the emperor. ${ }^{4}$

${ }^{3}$ Giorgio Chittolini, "Cities, City-States, and Regional States in North-Central Italy," in Giorgio Chittolini, Wim Blockmans and Charles Tilly, eds., Cities and States in Europe, 1000-1800, special issue of Theory and Society, 18 (1989), 689-706, 690ff.; Philip Jones, The Italian City-State: From Commune to Signoria (Oxford, 1997), 55ff.; Sauro Gelichi, “The Cities," in Cristina La Rocca, ed., Italy in the Early Middle Ages (Oxford, 2002), 168-188; Città e campagna nei secoli altomedievali, I-II (Spoleto, 2007); Tom Scott, The City-State in Europe, 1000-1600 (Oxford, 2012), $24 \mathrm{ff}$.

${ }^{4}$ Giovanni Tabacco, Struggle for Power in Medieval Italy: Structures of Political Rule (Cambridge, 1990), $182 \mathrm{ff}$. 
The emergence of city communes in the eleventh and twelfth centuries marked a further turning point. These new institutions, in fact, not only emancipated themselves from the episcopal government but also started, albeit step by step, a process of political expansion into the surrounding countryside. For the municipality, this projection constituted a strategic objective; it was a matter of asserting control over the main trading routes, ports, and other locations relevant to traffic and trade. Furthermore, communes wished to exercise direct control over the lands from which the rations were supplied and on which the investments of the citizens were concentrated. In forms that were at first very pragmatic (through political agreements, land acquisitions and rights, and the construction of hamlets and villages) and then through increasingly aggressive means (military expeditions), the city communes gradually expanded their spheres of influence, which, from the ideal perspective, came to be identified with the entire diocese. 5

In line with these developments, the sources attributable to the civitas tend to represent the relationship between cities and countryside in a new way. As early as the beginning of the twelfth century, this relationship is expressed in terms of belonging, with the countryside being subordinated to the urban center, as the verbs and adjectives of possession clearly indicate. ${ }^{6}$ Increasingly, in fact, the cives began to indicate the city district (the part of the rural territory governed by the urban commune) as comitatus civitatis, i.e., using a lexeme that, while creating a legitimizing continuity with the Carolingian era (the comitatus was originally a public district extended to the countryside and subject to the count), ended up replacing the figure of the comes (count) with that of civitas. This difference was substantial and had important implications. The civitas was no longer just the administrative center of the surrounding countryside (as had been the case in the Carolingian era, when the count used to have his residence in the city), but was in effect a political constituency. In other words, if until the tenth century, the city and the countryside together formed the comitatus and were subject to the power of the count, after that date the comitatus came to be subordinate to the city government.

In the context of this reconfiguration, the ways in which the cives presented their new condition of dependence on the inhabitants of the comitatus also changed. It is precisely at this stage that corporeal metaphors began to emerge in the municipal sources. Citizens present the

\footnotetext{
5 Jones, The Italian City-State, 152ff; Giorgio Chittolini, "The Italian City-State and its Territory," in Anthony Molho, Kurt Raaflaub and Julia Emlen, eds., City States in Classical Antiquity and Medieval Italy (Stuttgart, 1991), 589-602.

${ }^{6}$ Giuseppe De Vergottini, “Origini e sviluppo storico della comitatinanza,” Studi Senesi, 2, XVIII (1929), repr. in idem, Scritti di storia del diritto italiano, ed. Guido Rossi (Milan, 1977), I, 3-122, 64, 72, 76ff. 
process of communal expansion in the countryside as the restoration of an original condition, which saw cities and countryside linked through a natural, albeit asymmetrical relationship. This condition is illustrated through two powerful metaphors: one that represents the city as the "mother," and the inhabitants of the comitatus, the comitatini, as the "children"; and the other that depicts the city as the "head," and the inhabitants of the countryside as the "limbs" of the same body. In the documents, we find many testimonies of such an understanding, which have already attracted the attention of legal historians such as Giuseppe De Vergottini in the scholarship of the last hundred years. ${ }^{7}$ I will limit myself here to recalling one of those testimonies which, however, seems extraordinarily telling. It is a passage in the chronicle written in the second half of the twelfth century by the chancellor of the commune of Genoa, Oberto, who continued the work begun by the famous Caffaro. ${ }^{8}$ Broaching the topic of discord in Genoa's civic body, the author stresses the relationship between those struggles and the political instability of the countryside, where the peasants had begun to rebel against the cives. He expressed his view of the matter in the following terms:

As a consequence, the limbs of a body suffer when they feel that the head is suffering. So it is not strange if the limbs of the city [i.e., the countryside, the rural areas] were destroyed when the mother of all and also the head, that is our city, suffered even more than one could believe. ${ }^{9}$

The uniqueness of this text lies in its combining both metaphors mentioned earlier, i.e., the metaphor of mother and children, and that of head and limbs. However, it is a characteristic trait of the textuality of the high and late-communal age that both metaphors were frequently and alternately invoked, as if to figure as the corollary of the expansion of the sphere of the common

\footnotetext{
7 Ibid., $65 \mathrm{ff}$.

${ }^{8}$ On this extraordinary chronicle, see Henrike Haug, Annales Ianuenses. Orte und Medien des historischen Gedächtnisses im mittelalterlichen Genua (Göttingen, 2016).
}

${ }^{9}$ Annali Genovesi di Caffaro e de' suoi continuatori. Dal MXCIX al MCCXCIII, (Genoa, 1890), vol. 1, 219-220: "Merito enim cuiusque corporis membra patiuntur, cum caput pati sentitur. Ni mirum igitur si membra civitatis cassabantur, cum mater omnium et caput, id est civitas nostra, ultra etiam quam sit credendum patiebatur." On this passage, see also Vito Piergiovanni, "I rapporti giuridici tra Genova e il dominio," in Norme, scienza e prativa giuridica tra Genova e l'Occidente medievale e moderno, I, thematic issue of Atti della Società Ligure di Storia Patria, n.s., LII (CXXVI), fasc. 1 (2012), 123-140, 124. 
citizen into the surrounding territory. We encounter them in the statutes, in the letters, and in the chronicles.

Intriguingly, even the communities of the countryside adopted these images, although they implied a relationship of subordination. This usually occurred when some hamlet or village, so as to escape the control of a power perceived to be particularly hostile (or as not particularly advantageous), preferred to give itself to a city commune, the political language of which it therefore instrumentally adopted. One example is the case of the village of Carmignano, which found itself in the Pistoia comitatus but which was eager to pass under the dominion of Florence. In the letter addressed to the Florentine authorities "by your devout sons, that is by the community and all the men and people of Carmignano" ("pro parte devotorum filiorum vestrorum Communis et Universitatis hominum et personarum de Carmignano"), the supplicants, after decrying the condition of decadence of their ancient mother, the city of Pistoia, declared their desire to submit themselves to Florentine control. ${ }^{10}$

While between the twelfth and the early fourteenth centuries, corporeal metaphors lent themselves well to the portrayal of the territorial conquests which expanded the sphere of the common citizen, in the next two centuries, its function was more limited and oriented towards preserving and maintaining the territorial balance achieved by the civitates. Even the contents of the metaphor changed, as it was reconfigured to match the new political context.

The pioneering studies of Giorgio Chittolini have highlighted the legacy of the communal heritage for the regional states (the Duchy of Milan, the Republic of Venice, Florentine Tuscany, etc.), formations that were either enlarged and reduced through the aggregation or loss of cities with their respective contadi. It is as if these city-countryside continua represented the bricks used to build the new, broader political structures. ${ }^{11}$ This constitutional dynamic which saw the contadi evolve into province-like subdivisions of the regional state, initially seemed also to guarantee the maintenance of an urban-centric system in the ordering of territory. ${ }^{12}$ In reality, however, this did not last for long; the rulers soon intervened to reshape these structures, with the aim of securing the

\footnotetext{
10 "Prefatum Commune et Universitas de Carmigano, eiusdem communis antiqua matre civitate Pistorii with instantiam and precibus Communis Florentie predicti totaliter derelicta sub et cum certis pactis, modis et tenoribus, sub iurisdictione Communis Florentie solemniter se submisit." Cited from De Vergottini, "Origini e sviluppo storico della comitatinanza," 67.

${ }^{11}$ Chittolini, "Cities, City-States, and Regional States," 693ff.

12 Giorgio Chittolini and Dietmar Willoweit, eds., L'organizzazione del territorio in Italia e Germania.
} Secoli XIII-XIV (Bologna, 1994). 
goodwill of all those subjects - rural communities, villages, or castle lords - who struggled against their subordinate position versus the city in fiscal and jurisdictional terms. The success of the regional state passed along the lines of the direct relationship with the many territorial bodies.

A case in point is that of the Visconti, and the Sforza by whom they were succeeded in 1450; starting from their dominion over Milan, the Visconti were able to incorporate a large number of cities (with their contadi or territories) into an ever-larger realm. While constantly seeking a political axis with urban centers and their ruling classes, the Visconti and Sforza families were anything but insensitive to the demands for autonomy made by some political actors in the countryside. Accordingly, they granted them the privileges that sometimes even included exemption from the jurisdiction of the urban center. ${ }^{13}$ Villages and communities given these concessions would now be under the jurisdiction of the rural lord. The cities put up a strong resistance against what they perceived to be real territorial "amputations". The urban centers appealed, in fact, to the maintenance of the unity of the political body, the guarantor of which had to be the lord. ${ }^{14}$

The corporeal metaphors returned in this novel constellation. The examples, once again, are numerous and emerge with particular frequently on the occasion of dynastic successions, when it was a tradition that the communes of the domain, having reaffirmed their loyalty to the new lord, presented him with petitions. Consider the series of requests that the municipality of Parma handed in to the Duke Filippo Maria Visconti in 1421. This is a long list, organized into a series of points, where we may read as follows:

Given that multiple villages (terrae) in the diocese of Parma have been for a long time made exempt from the district of Parma [...], and provided that, as is commonly said, the body

\footnotetext{
${ }^{13}$ On state formation in late medieval Lombardy, see Federico Del Tredici, "Lombardy under the Visconti and the Sforza," in Gamberini and Lazzarini, eds., The Italian Renaissance State, 156-176; Andrea Gamberini, "Milan and Lombardy in the Era of the Visconti and the Sforza," in idem, ed., A Companion to Late Medieval and Early Modern Milan. The Distinctive Features of an Italian State (Leiden, 2015), 19-45.

14 Giorgio Chittolini, "Models of Government from below in Fifteenth-Century Lombardy," in Wim Blockmans, André Holenstein, Jon Mathieu and Daniel Schlappi, eds., Empowering Interactions. Political Cultures and the Emergence of the State in Europe 1300-1900 (Farnham, 2009), 51-63.
} 
without its limbs cannot long survive, we ask that His Grace the Duke would like those exempted villages to be returned to obedience to the city. ${ }^{15}$

The novelty when compared with previous centuries is substantial. The city is still framed by the corporeal metaphor, within which, however, it now seems to renounce the leading role. With its concern not to irritate the dominus, the true new caput (head) of the political organism, the city repositioned the emphasis on the unity and cohesion of the body politic and the importance of mitigating the damages inflicted by territorial amputations. ${ }^{16}$

An even more urgent example of self-censorship can be seen in that of Pavia, which, despite complaining to Filippo Maria that it was "deprived of most of its limbs" ("privata membris suis pro maiori parte"), leaves the metaphor incomplete, failing to elaborate on the functions of head or body. ${ }^{17}$ In reality, the cities had by no means renounced to the role of caput; as could be seen in 1447, when Duke Filippo Maria died without heirs. The cities sought to exploit the structural crisis into which the duchy was now plunged, believing that they could use it to recover their lost autonomy. This was a dream of short duration, however, since, after a couple of years, the condottiero Francesco Sforza, son-in-law of the deceased duke, waged a campaign of re-conquest, city by city, of the ancient duchy. There are very striking differences in the ways in which various cities, starting with Parma, addressed themselves to the new lord. Mindful of the glorious past that had, albeit briefly, recently been revived, some city-communes did not hesitate to expound to Sforza, who was, in their eyes, nothing more than a parvenu and devoid of the ducal title, glorious historical imagery that assigned the role of head to the civitas. In the capitoli (pacts of submission) presented to Sforza, the city of Parma demanded, for example, the following: "The aforementioned 15 Angelo Pezzana, Storia della città di Parma, II, Appendice (Parma, 1842), 23: "Item quod multae terrae episcopatus Parmae iam diu steterunt exempte a civitate Parme [...] et qui vulgariter dicitur quod corpus sine membris suis non posset diu permanere, dignetur predictus Dominus omnes villas et terras dicti episcopatus nunc exemptas reducere ad obedientiam civitatis Parme." On this passage, see also Marco Gentile, Terra e poteri. Parma e il parmense nel ducato visconteo all'inizio del Quattrocento (Milan, 2001), 34 n.10.

${ }^{16}$ Some urban centers adopted a similar position in the ways they related to the Church. In the supplications to the sovereign pontiff, the cities did not present themselves as "heads," but as tutors of the unity of the body. See the texts quoted by Sandro Carocci, "Governo papale e città nello stato della Chiesa. Ricerche sul Quattrocento," in Sergio Gensini, ed., Principi e città alla fine del medioevo (Rome, 1996), 151-224, 204-205.

17 Pietro Ciapessoni, "Per la storia della economia e della finanza pubblica pavesi, sotto Filippo Maria Visconti," Bollettino della Società Pavese di Storia Patria, 6 (1906), 173-234, 609-645, esp. 628. 
lord is obliged to reintegrate the city and the episcopate of Parma within its borders, at its head and in its limbs."18 Lodi was equally bold: "Since the head without the limbs means the death of the cities, we ask that all the castles, villages, and places of the diocese of Lodi be united and submitted to the city." 19 But not everywhere were the cities so enterprising and resourceful. In certain cases, the request to Sforza for territorial reintegration, though clearly formulated, involved no corporeal metaphors, whereas in others, as was the case with Tortona, the city commune demanded that the "limbs be reintegrated," but - as we have already seen in the above-mentioned case of Pavia without the urban center being assigned an explicit role in the metaphor. ${ }^{20}$

In 1450, Francesco Sforza clarified the role of the cities within the ducal body, expressing his thoughts in an edict addressed to the commune of Milan. He first recalled that the revenue represented "the principal parts and nerves of our state" ("principales partes et nervi status nostri") employing another somatic metaphor, this time referring to the duchy. The new prince then decreed that the privileges of all those in the countryside of Milan who claimed the right not to contribute to the taxation of the state were to be subject to verification. Those terrae (communities) that had not been made exempt by virtue of some charter should from then on be considered to be "limbs of the city of Milan" and should therefore be subject to ducal taxation ("ex nunc intelligantur civitatis nostre Mediolani membra esse et ad Cameram nostram pertienant"). ${ }^{21}$ For the new duke, the lands of the countryside clearly formed a part of the same body as the city. Note, however, that he was cautious in leaving open whether the city should be considered the head.

The different ways in which cities were represented, with some sometimes portraying themselves as the caput and at other times as the corpus, signals better than protracted explanations the tensions that persisted between the never-dormant ambitions of urban communes and the necessity on their part to submit to changes in the balance of power. At any rate, the cities continued to play their games at a different level, not directly or explicitly involving the duke, in affirming and upholding the dependence of the countryside, through a corporeal vocabulary. Over the course of

18 Pezzana, Storia della città di Parma, V, Appendice, 21: "El prefato signore sia tenuto et obligato a sue spexe reintegrare la città e l'episcopato di Parma entro i suoi confini, nel capo e nelle membra."

19 Cesare Vignati, ed., Codice Diplomatico Laudense, vol. II (Lodi, 1885), 519: “Quia caput sine membris interitum civitatum indicat [...] omnia castra, omnes quoque ville, terra et loca episcopatus Laude uniantur et submittantur ipsi civitati."

20 On Tortona, see Giorgio Chittolini, Città, comunità e feudi negli stati dell'Italia centro-settentrionale (secoli XIV-XVI) (Milan, 1996), 51 n.35.

${ }^{21}$ Carlo Morbio, Codice Visconteo-Sforzesco (Milan, 1846), 340-341. 
time, many communes had, in fact, cultivated rituals in which the inhabitants of the countryside were obliged to participate, with the aim of putting on dramatic display the union of the countryside with the civitas, and the subordination of the first to the second. The most characteristic practice was the procession that would be held in the city on the day of the feast of the Virgin, of the patron saint or of Corpus Domini, and also involved the communities of the countryside, which were obliged to send their representatives to the city, usually to the cathedral, with offerings for the church wherein the rite culminated. On these occasions, a large parade was generally held, attended by the clergy, city magistrates, and corporations; they were followed by citizenry and last by the envoys of the communities of the countryside. Through recourse to that typically late-communal phenomenon that is civic Christianity, that is, religiosity oriented in its manifestations and contents by city institutions, it was possible to stage (and therefore affirm) the compactness of the body politic and its subordination to the city commune..$^{22}$

It is worthwhile dwelling on these aspects because when the lords of Milan resolved to represent the unity of the new and wider political body that they were building (i.e., the regional state), it was to the very rituals of the city and communal matrix that they were drawn. Rooted in a social setting that revolved around the political or religious language of a most directly legitimizing and immediately understandable power, civic rituals were well suited, with small readjustments, to represent also the new and wider state organism. The earliest testimony in this regard is provided by the Milanese chronicler Galvano Fiamma (1283-1344), who relates that Azzone Visconti - the true founder of a state of regional dimensions - introduced the ritual in 1335, whereby the dominus himself, and the representatives of all cities and villages of the domain (Fiamma speaks of 122), presented an offer of silk cloths with banners of all their communities to the cathedral of Milan on the day of the Nativity of the Virgin (September 8$) .23$

22 Giorgio Chittolini, "Civic Religion and Late Medieval Italy," in Trevor Dean and Chris Wickham, eds., City and Countryside in Late Medieval and Renaissance Italy: Essays Presented to Philip Jones (London, 1990), 69-80.

${ }^{23}$ Galvano Fiamma, Opusculum de rebus gestis ab Azone, Luchino and Joanne Vicecominibus ab anno MCCCXXVIIII usque ad annum MCCCXLII, ed. by Carlo Castiglioni, in Giosuè Carducci and Vittorio Fiorini, eds., Rerum Italicarum Scriptores, vol. 12, (Bologna, 1938), col. 1017. Significantly, only a few months earlier, Giovanni Visconti had introduced the feast of Corpus Domini to Milan, another occasion in which the political body of the civitas gathered together; see Guido Cariboni, "Il culto, la festa e la processione del Corpus Domini a Milano presso i primi Visconti," in Laura Andreani and Agostino Paravicini Bagliani, eds., Il “corpus Domini.” Teologia, antropologia e politica (Florence, 2015), 259-271. 
It is worth noting that a simplified version of this representation also appears carved on the tomb of Azzone himself. While the lid depicts the gisant of the lord, the three sides show personifications of the Lombard cities (Lodi, Como, Bergamo, Brescia, Piacenza, etc.), each introduced by the respective patron saint, all intent on paying homage to Saint Ambrose, protector of Milan. Commissioned by Azzone himself and built between 1342 and 1346 by the famous Giovanni di Balduccio, this iconography figuratively translates the message that the processions introduced by Azzone wished to assert. ${ }^{24}$ There is no need to mull over the differences - albeit considerable - between the ritual actually promoted by Azzone (according to Fiamma) and the one depicted on his funeral monument. ${ }^{25}$ Instead, it is important to emphasize the insistence in both on a corporeal representation of society and its many articulations - in short, the political body.

The culmination of this process of appropriation by the lords of a communal ritual was achieved in 1402, following the death of Gian Galeazzo Visconti, who had not only acquired the ducal title for himself and his offspring but had also expanded his dominion to its outmost limits. It was in the difficult situation precipitated by his death, when the first mutinous noises began to be heard from the restless peripheries of the duchy, that the court decided to react to the centrifugal forces by reaffirming the compactness of its territory with a pompous state ritual. The public funeral of the duke thus became a sumptuous and solemn celebration of the unity of the state's political body. Around the body of the duke - the personification of the duchy and its caput - the constituent parts of the domain, the "limbs," paraded: not only the representatives of the cities but also those of

\footnotetext{
${ }^{24}$ Patrick Boucheron, “Tout est monument. Le mausolée d'Azzone Visconti in San Gottardo in Corte (Milan, 1342-1346)," in Jean-Marie Martin and Dominique Barthélemy, eds., Liber largitorius. Etudes d'histoire médiévale offertes à Pierre Toubert par ses élèves (Geneva, 2003), 303-329, esp. 320; Evelyn Welch, Art and Authority in Renaissance Milan (New Haven, CT, and London, 1995), 18-21.

25 The differences are well captured by Federica Cengarle, "I Visconti e il culto della Vergine (XIV secolo): qualche osservazione," in Laura Gaffuri and Paola Ventrone, eds., Immagini, culti, liturgie. Le connotazioni politiche del messaggio religioso, thematic issue of Annali di storia moderna e contemporanea, 16 (2010), 215-228, esp. 218-219.
} 
large and small communities, as well as feudal lords. ${ }^{26}$ It was a complex and articulated ritual, which somehow refined and implemented the allegory carved onto the tomb of Azzone.

It was not only through the mediation of communal rituals that the Visconti reworked the corporeal metaphors. The quest for sacred legitimation led the lords of Milan to undertake a Christomimetic representation of their power. Particularly interesting is the decree issued on 8 October 1370, by Galeazzo II (1320-1378), which establishes an analogy between those who do not recognize the incarnate God, such as the Jews and the infidels, and those who do not recognize and therefore betray - the lord of Milan. As the great jurist Bartolo da Sassoferrato noted, "the prince is God on Earth" ("princeps est Deus in Terris"). ${ }^{27}$ Infractions of this law, which equates the denial of the princeps with the denial of God, led Galeazzo II to impose a penalty inspired by the principle of contrappasso (retaliation). His argument was straightforward: since in many Christian lands, "they have [the infidels] hanged for their feet so that those who do not recognize their head, that is Christ, be punished with the head down," ("illos pedes suspendi faciunt ut qui caput suum, idest Christum, penitus non cognoscunt, everso capite puniantur"), Galeazzo II now orders, “in analogy to what has been said" ("ad similitudinem premissorum") that whoever betrays the prince and tries to subvert the state is also hanged with their head down.28 The corporeal metaphor could not be more explicit here: mystical body and political body refer to each other, owing to the sacred function of the prince.

To complete this picture, we may observe that the cities and the dukes were not the only ones to draw upon a rich repertoire of corporeal imagery for pragmatic purposes. Subjects also sometimes resorted to them in their supplications; for example, Donnina Fondulo, wife of Cabrino and marquise of Castelleone, wrote to the podestà of Cremona complaining that the waterways of

26 The ordo funeris, expertly organized by the "primus camerarius" Francesco Barbavara, is published in Ludovico Antonio Muratori, ed., "Ordo funeris domini Iohannis Galeaz Vicecomitis," in Rerum Italicarum Scriptores, vol. 16 (Milan, 1730), coll. 1021-1035. A second description of the funeral is provided by the Sienese writer Pietro Cantarino; see Barbara Pagliari, I funerali di Gian Galeazzo Visconti di Pietro cantarino da Siena (PhD diss., University of Lausanne, 2018). More generally, on the symbolic value of Gian Galeazzo's funeral, see Federico Del Tredici, Un'altra nobiltà. Storie di (in)distinzione a Milano. Secoli XIV-XV (Milan, 2017), 117ff.

${ }^{27}$ Michael Wilks, The Problem of Sovereignty in the Later Middle Ages (Cambridge, 1963), 168 n.3.

${ }^{28}$ Federica Cengarle, Lesa maestà all'ombra del biscione. Dalle città lombarde a una "Monarchia europea" (1335-1447) (Rome, 2014), 134-135. 
which the podestà wanted to deprive her were "a single body" ("unum corpus") with her husband's possessions: indeed, they were the limbs of that body!29

At the beginning of the fifteenth century, the rising social order of the bureaucrats also made extensive use of that image. Powerful officials (albeit generally of humble origins) discerned in the corporeal metaphor some potential for their ennoblement. The growth of the regional state was accompanied by the development at its core of new decision-making offices (the Chancellery, the Secret Council, the Council of Justice, the Revenue Magistracy, etc.), in which - in the case of the Chancellery - the selection criteria of the staff rewarded competence over nobility. As a result, the senior posts of the state ended up being held by individuals who were prepared but not personally vested with individual prestige. It was against this backdrop that the chancellor Uberto Decembrio (1350-1427) - the one who first translated Plato's Republic in 1400-1402 from Greek into Latin wrote a treatise, the De Republica libri quattuor, in which he reworked, in an absolutely novel way, a number of the ideas of the great Greek philosopher. ${ }^{30}$ While Plato, as is well known, had theorized a tripartite society, in which those with a golden nature govern, those with a silver nature militate as custodes, and those with a bronze nature are destined for the group of workers (414B-415B), Decembrio reconfigures the social hierarchies so as to give prominence to the category of officials. The tool he uses relies once more on the corporeal metaphor, for Uberto writes that the state resembles a body, in which the prince is the head; the custodes (military) the chest; the artifices (artisans), mercatores (merchants), and agricolae (farmers) the hands and arms; and the "praesides et officiales" - high magistrates and bureaucrats - are the feet and shins, or those supporting the state itself! ${ }^{31}$ In this case, the corporeal metaphor was not deployed to assert the unity of the political body, but to insert a component with a significant role, which had up to then lacked any explicit recognition.

\section{Final Remarks}

29 The letter is preserved at the Biblioteca Statale, Cremona, BB.2.5.2 (141-160) and is dated Castelleone, 15 July 1420 .

${ }^{30}$ Cf. Mario Vegetti and Paolo Pissavino, eds., Decembrio e la tradizione della Repubblica di Platone tra Medioevo e umanesimo (Naples, 2005); Franca Gusmini, "Le traduzioni della Repubblica platonica di Uberto e Pier Candido Decembrio: primi accertamenti testuali," Filologia italiana, 9 (2012), 77-108.

${ }^{31}$ Andrea Gamberini, “'I piedi e le tibie’ dello stato: gli officiali. Legittimazione e costruzione identitaria di un nuovo ceto politico nelle parole di Uberto Decembrio," in idem, ed., La mobilità sociale nel Medioevo italiano. 2: Stato e istituzioni (secoli XIV-XV) (Rome, 2017), 99-115, 108. 
There are numerous testimonies of the use of corporeal metaphors in the communal and postcommunal age that show their use by different political actors, each - as we have seen - motivated by a particular purpose and agenda. It is interesting to focus on the ways in which the metaphor functioned in the specific historical context that has been considered in this article. In general, scholarship has understood the distorting force of the metaphor well, which is never neutral but contributes to an interpretation of the material that it thereby organizes. Establishing a parallel between different subjects means creating links and hierarchies that did not previously exist in rebus, but which are the fruits of a mental construct. ${ }^{32}$

However, in the case of the corporeal metaphors, there is more to the story. Postulating a bodily analogy between the city and the countryside allows for a combination of a hierarchical principle with a unitary one. For, above all, it conveys the notion that all are made of the same substance. Whether they are distinct bodies linked by a filial relationship (e.g., the comitatini filii and the civitas mater), or different organs that are parts of the same body (with the limbs governed by the head), the matter of which they are made, the blood that runs through the veins was, for everyone, the same. The metaphor is therefore a powerful ideological filter, which helps to forge a strong sense of communion. The extraordinary potential of this communicative medium is obvious. To affirm the consubstantiality between city and countryside, or between ordinary citizens and the regional state, means to postulate a unity of political and juridical cultures that bridges the gap between actors. This was actually an important novelty: to the question, "what justifies obedience to a superior power?", the many protagonists (cities, communities, rural lords, classes, princes, etc.) not only provided different responses, but their responses were also all rooted in different cultural backgrounds. Some referred to customs, others to Roman law, and others still to new and state-like political cultures. Without going into further detail on the divergence of these cultural backgrounds, it must suffice here to recognize the intense game that was fought around the theme of the legitimacy of power - a game in which the rules were not always shared. ${ }^{33}$

From this perspective, the function and appeal of the corporeal metaphors is clear. The postulate of shared political norms, laws, and cultures was a prerequisite for incorporating society into an institutionally coherent and hierarchically subordinated institutional system - a subordination to the city in the communal era and to the prince in the post-communal era. There was no space left for dissent. In short, the metaphor eventually paved the way for the use of the law

\footnotetext{
32 Briguglia, Il corpo vivente dello stato, 45.

${ }^{33}$ Andrea Gamberini, The Clash of Legitimacies: The State-Building Process in Late Medieval Lombardy (Oxford, 2018).
} 
(first by the city communes, then by the dukes) as the only framework of legitimacy and, at the same time, as the tool for the affirmation of that very legitimacy. In the logic of that context, a violation of obligations that are both moral and natural (as in the case of the duties of children towards the mother, or of the limbs towards the body) constitutes a real "rebellion," which the law must punish with the most severe penalties. ${ }^{34}$

${ }^{34}$ Quotation from De Vergottini, “Origine e sviluppo della comitatinanza," §24. On these aspects, see Gamberini, Clash of Legitimacies, 68ff; also Jane Black, Absolutism in Renaissance Milan. Plenitude of Power under the Visconti and the Sforza, 1329-1535 (Oxford, 2009). 